\title{
THE CHINESE UNIVERSITY OF HONG KONG
}

Applications are invited for:-

\section{Department of Systems Engineering and Engineering Management Postdoctoral Fellow(s)}

(Ref. 07/127(456)/3)

Applicants should have (i) a doctoral degree; and (ii) outstanding academic record and firm commitment to excellent research in financial engineering, information systems, logistics and supply chain management, optimization and operations research, or related areas. Appointment(s) will initially be made on contract basis for one year, renewable subject to mutual agreement. Applications will be accepted until the post is filled.

\section{Salary and Fringe Benefits}

Salary will be highly competitive, commensurate with qualifications and experience. The University offers a comprehensive fringe benefit package, including medical care.

Further information about the University and the general terms of service for appointments is available at $h t t p: / / w w w . c u h k . e d u . h k / p e r s o n n e l$. The terms mentioned herein are for reference only and are subject to revision by the University.

\section{Application Procedure}

Please send full resume, together with copies of qualification documents, should reach the Department of Systems Engineering and Engineering Management, The Chinese University of Hong Kong, Shatin, N.T., Hong Kong.

The Personal Information Collection Statement will be provided upon request. Please quote the reference number and mark "Application - Confidential" on cover. 


\section{STATEMENT OF OWNERSHIP, MANAGEMENT, AND CIRCULATION}

The Journal of Financial and Quantitative Analysis (ISSN 0022-1090) is published quarterly (4 issues per year) by University of Washington School of Business Administration, a nonprofit organization located at 115 Lewis, Seattle, WA 98195-3200. The Managing Editor is Paul Malatesta, School of Business Administration, University of Washington, 115 Lewis, Box 353200, Seattle, WA 98195-3200. There are no known bondholders, mortgagees, or other security holders owning or holding 1 percent or more of total amount of bonds, mortgages, or other securities. The purpose, function, and nonprofit status of this organization and the exempt status for federal income tax purposes have not changed during the preceding 12 months. The annual subscription price for the Journal of Financial and Quantitative Analysis is $\$ 160 / \$ 170$ for institutions and $\$ 80 / \$ 90$ for individuals. During the preceding 12 months, the average number of copies printed for each issue was 2,600; the average paid circulation 2,232; the average free distribution 67; the average number of copies distributed 2,300. Corresponding figures for the last issue before filing: total number of copies printed 2,600; total paid circulation 2,238; free copies distributed 68; total distribution 2,306. Average percent paid $97 \%$; actual percent paid $97 \%$.

I certify that the statements made by me above are correct and complete.

Ms. Marty Auvil

Editor, Journal of Financial and Quantitative Analysis

(This statement is for 2007.) 


\section{JFQA Volume 42 Index}

Anand, A., and S. Chakravarty, Stealth Trading in Options Markets, March, 167-187.

Ang, A., L. Gu, and Y. V. Hochberg, Is IPO Underperformance a Peso Problem?, Sept., 565594.

Bamber, L. S., M. C. Dawkins, and N. Bhattacharya, Systematic Share Price Fluctuations after Bankruptcy Filings and the Investors Who Drive Them, June, 399-419.

Banerjee, S., V. A. Gatchev, and P. A. Spindt, Stock Market Liquidity and Firm Dividend Policy, June, 369-397.

Bhattacharya, N., M. C. Dawkins, and L. S. Bamber, Systematic Share Price Fluctuations after Bankruptcy Filings and the Investors Who Drive Them, June, 399-419.

Binay, M. M., V. A. Gatchev, and C. A. Pirinsky, The Role of Underwriter-Investor Relationships in the IPO Process, Sept., 785-809.

Boes, M.-J., F. C. Drost, and B. J. M. Werker, The Impact of Overnight Periods on Option Pricing, June, 517-533.

Bollen, N. P. B., Mutual Fund Attributes and Investor Behavior, Sept., 683-708.

Broadie, M., and Ö. Kaya, A Binomial Lattice Method for Pricing Corporate Debt and Modeling Chapter 11 Proceedings, June, 279-312.

Carrieri, F., V. Errunza, and K. Hogan, Characterizing World Market Integration through Time, Dec., 915-940.

Chakravarty, S., and A. Anand, Stealth Trading in Options Markets, March, 167-187.

Chan, L. K. C., J. Karceski, and J. Lakonishok, Analysts' Conflicts of Interest and Biases in Earnings Forecasts, Dec., 893-914.

Chang, H.-C., and S.-L. Chung, Generalized Analytical Upper Bounds for American Option Prices, March, 209-227.

Chen, Y., and B. Liang, Do Market Timing Hedge Funds Time the Market?, Dec., 827-856.

Choi, J. J., S. W. Park, and S. S. Yoo, The Value of Outside Directors: Evidence from Corporate Governance Reform in Korea, Dec., 941-962.

Chung, K. H., and X. Zhao, Information Disclosure and Market Quality: The Effect of SEC Rule 605 on Trading Costs, Sept., 657-682.

Chung, S.-L., and H.-C. Chang, Generalized Analytical Upper Bounds for American Option Prices, March, 209-227.

Cleary, S., P. Povel, and M. Raith, The U-Shaped Investment Curve: Theory and Evidence, March, 1-39.

Dahya, J., and J. J. McConnell, Board Composition, Corporate Performance, and the Cadbury Committee Recommendation, Sept., 535-564.

Danielsen, B. R., B. F. Van Ness, and R. S. Warr, Reassessing the Impact of Option Introductions on Market Quality: A Less Restrictive Test for Event-Date Effects, Dec., 1041-1062.

Dark, J., Basis Convergence and Long Memory in Volatility When Dynamic Hedging with Futures, Dec., 1021-1040.

Dawkins, M. C., N. Bhattacharya, and L. S. Bamber, Systematic Share Price Fluctuations after Bankruptcy Filings and the Investors Who Drive Them, June, 399-419.

Denis, D. K., and K. J. Rodgers, Chapter 11: Duration, Outcome, and Post-Reorganization Performance, March, 101-118.

Drost, F. C., M.-J. Boes, and B. J. M. Werker, The Impact of Overnight Periods on Option Pricing, June, 517-533.

Elton, E. J., M. J. Gruber, and T. C. Green, The Impact of Mutual Fund Family Membership on Investor Risk, June, 257-277.

Errunza, V., F. Carrieri, and K. Hogan, Characterizing World Market Integration through Time, Dec., 915-940.

Farnsworth, H., and T. Li, The Dynamics of Credit Spreads and Ratings Migrations, Sept., 595620.

Ferris, S. P., T. Jandik, R. M. Lawless, and A. Makhija, Derivative Lawsuits as a Corporate Governance Mechanism: Empirical Evidence on Board Changes Surrounding Filings, March, 143-165.

Gatchev, V. A., M. M. Binay, and C. A. Pirinsky, The Role of Underwriter-Investor Relationships in the IPO Process, Sept., 785-809.

Gatchev, V. A., S. Banerjee, and P. A. Spindt, Stock Market Liquidity and Firm Dividend Policy, June, 369-397.

Goldreich, D., Underpricing in Discriminatory and Uniform-Price Treasury Auctions, June, 443-466. 


\section{Volume 42 Index (continued)}

Green, T. C., E. J. Elton, and M. J. Gruber, The Impact of Mutual Fund Family Membership on Investor Risk, June, 257-277.

Gruber, M. J., E. J. Elton, and T. C. Green, The Impact of Mutual Fund Family Membership on Investor Risk, June, 257-277.

Gu, L., A. Ang, and Y. V. Hochberg, Is IPO Underperformance a Peso Problem?, Sept., 565594.

Guthrie, G., Missed Opportunities: Optimal Investment Timing When Information is Costly, June, 467-488.

Harrington, S. E., and D. G. Shrider, All Events Induce Variance: Analyzing Abnormal Returns When Effects Vary across Firms, March, 229-256.

Hautsch, N., and D. Hess, Bayesian Learning in Financial Markets: Testing for the Relevance of Information Precision in Price Discovery, March, 189-208.

Hess, D., and N. Hautsch, Bayesian Learning in Financial Markets: Testing for the Relevance of Information Precision in Price Discovery, March, 189-208.

Hochberg, Y. V., A. Ang, and L. Gu, Is IPO Underperformance a Peso Problem?, Sept., 565594.

Hodder, J. E., and J. C. Jackwerth, Incentive Contracts and Hedge Fund Management, Dec., 811-826.

Hogan, K., F. Carrieri, and V. Errunza, Characterizing World Market Integration through Time, Dec., 915-940.

Jackwerth, J. C., and J. E. Hodder, Incentive Contracts and Hedge Fund Management, Dec., 811-826.

Jandik, T., S. P. Ferris, R. M. Lawless, and A. Makhija, Derivative Lawsuits as a Corporate Governance Mechanism: Empirical Evidence on Board Changes Surrounding Filings, March, 143-165.

Kan, R., and G. Zhou, Optimal Portfolio Choice with Parameter Uncertainty, Sept., 621-656.

Karceski, J., L. K. C. Chan, and J. Lakonishok, Analysts' Conflicts of Interest and Biases in Earnings Forecasts, Dec., 893-914.

Kaya, Ö., and M. Broadie, A Binomial Lattice Method for Pricing Corporate Debt and Modeling Chapter 11 Proceedings, June, 279-312.

Klasa, S., Why Do Controlling Families of Public Firms Sell Their Remaining Ownership Stake?, June, 339-367.

Lakonishok, J., L. K. C. Chan, and J. Karceski, Analysts' Conflicts of Interest and Biases in Earnings Forecasts, Dec., 893-914.

Lam, S.-S., R. S.-K. Tan, and G. T.-M. Wee, Initial Public Offerings of State-Owned Enterprises: An International Study of Policy Risk, June, 313-337.

Lawless, R. M., S. P. Ferris, T. Jandik, and A. Makhija, Derivative Lawsuits as a Corporate Governance Mechanism: Empirical Evidence on Board Changes Surrounding Filings, March, 143-165.

Lee, B.-S., and O. M. Rui, Time-Series Behavior of Share Repurchases and Dividends, March, $119-142$.

$\mathrm{Li}, \mathrm{T}$., and H. Farnsworth, The Dynamics of Credit Spreads and Ratings Migrations, Sept., 595620.

Liang, B., and Y. Chen, Do Market Timing Hedge Funds Time the Market?, Dec., 827-856.

Makhija, A., S. P. Ferris, T. Jandik, and R. M. Lawless, Derivative Lawsuits as a Corporate Governance Mechanism: Empirical Evidence on Board Changes Surrounding Filings, March, 143-165.

Marosi, A., and N. Massoud, Why Do Firms Go Dark?, June, 421-442.

Massoud, N., and A. Marosi, Why Do Firms Go Dark?, June, 421-442.

McConnell, J. J., and J. Dahya, Board Composition, Corporate Performance, and the Cadbury Committee Recommendation, Sept., 535-564.

Moser, W. J., The Effect of Shareholder Taxes on Corporate Payout Choice, Dec., 991-1020.

Nardari, F., and J. T. Scruggs, Bayesian Analysis of Linear Factor Models with Latent Factors, Multivariate Stochastic Volatility, and APT Pricing Restrictions, Dec., 857-892.

Park, S. W., J. J. Choi, and S. S. Yoo, The Value of Outside Directors: Evidence from Corporate Governance Reform in Korea, Dec., 941-962.

Paul, D. L., Board Composition and Corrective Action: Evidence from Corporate Responses to Bad Acquisition Bids, Sept., 759-783.

Pirinsky, C. A., M. M. Binay, and V. A. Gatchev, The Role of Underwriter-Investor Relationships in the IPO Process, Sept., 785-809. 


\section{Volume 42 Index (continued)}

Post, T., and P. Versijp, Multivariate Tests for Stochastic Dominance Efficiency of a Given Portfolio, June, 489-515.

Povel, P., S. Cleary, and M. Raith, The U-Shaped Investment Curve: Theory and Evidence, March, 1-39.

Raith, M., S. Cleary, and P. Povel, The U-Shaped Investment Curve: Theory and Evidence, March, 1-39.

Rodgers, K. J., and D. K. Denis, Chapter 11: Duration, Outcome, and Post-Reorganization Performance, March, 101-118.

Rui, O. M., and B.-S. Lee, Time-Series Behavior of Share Repurchases and Dividends, March, $119-142$

Sarno, L., D. L. Thornton, and G. Valente, The Empirical Failure of the Expectations Hypothesis of the Term Structure of Bond Yields, March, 81-100.

Scruggs, J. T., and F. Nardari, Bayesian Analysis of Linear Factor Models with Latent Factors, Multivariate Stochastic Volatility, and APT Pricing Restrictions, Dec., 857-892.

Shrider, D. G., and S. E. Harrington, All Events Induce Variance: Analyzing Abnormal Returns When Effects Vary across Firms, March, 229-256.

Spindt, P. A., S. Banerjee, and V. A. Gatchev, Stock Market Liquidity and Firm Dividend Policy, June, 369-397.

Tan, S.-K., S.-S. Lam, R. and G. T.-M. Wee, Initial Public Offerings of State-Owned Enterprises: An International Study of Policy Risk, June, 313-337.

Tang, H., and Y. Xia, An International Examination of Affine Term Structure Models and the Expectations Hypothesis, March, 41-80.

Thornton, D. L., L. Sarno, and G. Valente, The Empirical Failure of the Expectations Hypothesis of the Term Structure of Bond Yields, March, 81-100.

Valente, G., L. Sarno, and D. L. Thornton, The Empirical Failure of the Expectations Hypothesis of the Term Structure of Bond Yields, March, 81-100.

Van Ness, B. F., B. R. Danielsen, and R. S. Warr, Reassessing the Impact of Option Introductions on Market Quality: A Less Restrictive Test for Event-Date Effects, Dec., 1041-1062.

Venkataraman, K., and A. C. Waisburd, The Value of the Designated Market Maker, Sept., 735-758.

Versijp, P., and T. Post, Multivariate Tests for Stochastic Dominance Efficiency of a Given Portfolio, June, 489-515.

Villanueva, O. M., Forecasting Currency Excess Returns: Can the Forward Bias Be Exploited?, Dec., 963-990.

Waisburd, A. C., and K. Venkataraman, The Value of the Designated Market Maker, Sept., 735-758.

Warr, R. S., B. R. Danielsen, and B. F. Van Ness, Reassessing the Impact of Option Introductions on Market Quality: A Less Restrictive Test for Event-Date Effects, Dec., 1041-1062.

Wee, G. T.-M., S.-S. Lam, and R. S.-K. Tan, Initial Public Offerings of State-Owned Enterprises: An International Study of Policy Risk, June, 313-337.

Werker, B. J. M., M.-J. Boes, and F. C. Drost, The Impact of Overnight Periods on Option Pricing, June, 517-533.

Xia, Y., and H. Tang, An International Examination of Affine Term Structure Models and the Expectations Hypothesis, March, 41-80.

Yoo, S. S., J. J. Choi, and S. W. Park, The Value of Outside Directors: Evidence from Corporate Governance Reform in Korea, Dec., 941-962.

Zhao, X., and K. H. Chung, Information Disclosure and Market Quality: The Effect of SEC Rule 605 on Trading Costs, Sept., 657-682.

Zhdanov, A., Competitive Equilibrium with Debt, Sept., 709-734.

Zhou, G., and R. Kan, Optimal Portfolio Choice with Parameter Uncertainty, Sept., 621-656. 


\section{JFQA Style Requirements}

Send manuscripts via e-mail in PDF, Word, or LaTeX. The cover page must show title, author name(s) and affiliation(s), e-mail address(es), and work phone number(s). The first page of text should include the title and a one-paragraph abstract of no more than 100 words. Manuscripts must be double-spaced on one side of the page. All sections of the paper, beginning with the introduction and ending with a conclusion or summary, must be numbered with Roman numerals. Subsection headings must be lettered A, B, C, etc.

The manuscript should explain its relation to other research in the field, especially recently published material. References cited in the text should be noted by the last name(s) of the author(s) followed by the publication year enclosed in parentheses without punctuation: Smith (1988). When a particular page, section, or equation is referred to, the reference also should be placed within parentheses: (Smith and Jones (1988), p. 222), (Green (1988a), eq. 3).

Lengthy mathematical proofs and extensive tables should be placed in an appendix or omitted from the manuscript entirely. In the latter case, the author may indicate in a footnote that proofs or tables are available on request. The author should make every effort to explain the meaning of mathematical proofs.

The author should check the manuscript for clarity, grammar, spelling, and punctuation to minimize editorial changes and the necessity of extensive corrections at the proof stage. All abbreviations must be defined.

Equations. All but very short mathematical expressions should be displayed on a separate line and centered. Important displayed equations must be identified by consecutive Arabic numerals in parentheses on the left. Expressions should be aligned and subscripts and superscripts clearly marked to avoid confusion.

Tables. Each table must be titled and numbered consecutively with Arabic numerals. Please check the text to make sure there is a reference to each table. General footnotes should be marked a, b, c, etc., for specific footnotes. Asterisks ${ }^{*}$ or ${ }^{* *}$ indicate significance at the $5 \%$ and $1 \%$ levels, respectively. The author should check tables to be sure that totals are correct and that the title, column headings, and footnotes clearly explain the content of the table. If tables are on separate pages at the end of the article, indicate approximate placement within the text.

Figures. Figures must be titled and numbered consecutively with Arabic numerals. Captions should present sufficient information to describe the purpose of the figure. Figures for accepted manuscripts must be of professional quality and ready for reproduction.

Footnotes. Footnotes must be double-spaced. Footnotes must not be used for the purpose of citation. Footnotes with extensive content should be avoided.

References. All works cited in the text must be alphabetically arranged in a double-spaced list at the end of the manuscript. Examples:

Brown, S., and J. Warner. "Using Daily Stock Returns: The Case of Event Studies." Journal of Financial Economics, 14 (1985), 1-31.

Ross, S. A. "Return Risk and Arbitrage." In Risk and Return in Finance, Vol. I, I. Friend and J. L. Bicksler, eds. Cambridge, MA: Ballinger (1977).

Titman, S.; K. C. Wei; and F. Xie. "Capital Investments and Stock Returns." Journal of Financial and Quantitative Analysis, 39 (2004), 677-700. 


\section{Forthcoming Articles}

Probability Judgment Error and Speculation in Laboratory Asset Market Bubbles

Lucy F. Ackert, Narat Charupat, Richard Deaves, and Brian D. Kluger

Hedge Funds for Retail Investors? An Examination of Hedged Mutual Funds

Vikas Agarwal, Nicole M. Boyson, and Narayan Y. Naik

Investment and Competition

Evrim Akdogu and Peter MacKay

Information and the Intermediary: Are Market Intermediaries Informed Traders in Electronic Markets?

Amber Anand and Avanidhar Subrahmanyam

The Determinants of Capital Structure: Capital Market Oriented versus Bank Oriented Institutions Antonios Antoniou, Yilmaz Guney, and Krishna Paudyal

Idiosyncratic Volatility and the Cross-Section of Expected Returns

Turan G. Bali and Nusret Cakici

Aggregate Earnings, Firm-Level Earnings, and Expected Stock Returns

Turan G. Bali, K. Ozgur Demirtas, and Hassan Tehranian

Money and the (C)CAPM

Ronald J. Balvers and Dayong Huang

Order Consolidation, Price Efficiency, and Extreme Liquidity Shocks

Michael J. Barclay, Terrence Hendershott, and Charles M. Jones

The Role of the Media in the Internet IPO Bubble

Utpal Bhattacharya, Neal Galpin, Rina Ray, and Xiaoyun Yu

Stock Market Participation and the Internet

Vicki Bogan

Conditional Return Smoothing in the Hedge Fund Industry

Nicolas P. B. Bollen and Veronika K. Pool

Can Tests Based on Option Hedging Errors Correctly Identify Volatility Risk Premia?

Nicole Branger and Christian Schlag

Commonality in Liquidity: A Global Perspective

Paul Brockman, Dennis Y. Chung, and Christophe Pérignon

Anchoring Bias in Consensus Forecasts and Its Effect On Market Prices Sean D. Campbell Steven A. Sharpe

Corporate Governance, Shareholder Rights, and Shareholder Rights Plans: Poison, Placebo, or Prescription?

Gary L. Caton and Jeremy Goh

Using Innovative Securities under Asymmetric Information: Why Do Some Firms Pay with

Contingent Value Rights?

Sris Chatterjee and An Yan

Control Transfers, Privatization, and Corporate Performance: Efficiency Gains in China's Listed

Companies

Gongmeng Chen, Michael Firth, Yu Xin, and Liping Xu

An Explicit, Multi-Factor Credit Default Swap Pricing Model with Correlated Factors

Ren-Raw Chen, Xiaolin Cheng, Frank J. Fabozzi, and Bo Liu

Stock Options and Total Payout

Charles J. Cuny, Gerald S. Martin, and John J. Puthenpurackal

Pseudo Market Timing: A Reappraisal

Magnus Dahlquist and Frank de Jong

Second Order Stochastic Dominance, Reward-Risk Portfolio Selection, and the CAPM

Enrico De Giorgi and Thierry Post

Star Power: The Effect of Morningstar Ratings on Mutual Fund Flow

Diane Del Guercio and Paula A. Tkac

Does Sentiment Drive the Retail Demand for IPOs?

Daniel Dorn 


\section{Forthcoming Articles (continued)}

Are the Wall Street Analyst Rankings Popularity Contests?

Douglas R. Emery and Xi Li

The Determinants of Credit Default Swap Premia

Jan Ericsson, Kris Jacobs, and Rodolfo Oviedo

International Diversification with Large- and Small-Cap Stocks

Cheol S. Eun, Wei Huang, and Sandy Lai

Sudden Deaths: Taking Stock of Geographic Ties

Mara Faccio and David C. Parsley

Founder-CEOs, Investment Decisions, and Stock Market Performance

Rüdiger Fahlenbrach

Asset Pricing Models with Conditional Betas and Alphas: The Effects of Data Snooping and Spurious Regression

Wayne E. Ferson, Sergei Sarkissian, and Timothy Simin

Institutional Versus Individual Investment in IPOs: The Importance of Firm Fundamentals

Laura Casares Field and Michelle Lowry

Style Investing and Institutional Investors

Kenneth Froot and Melvyn Teo

Blockholder Scarcity, Takeovers, and Ownership Structures

Gary Gorton and Matthias Kahl

Stock and Bond Market Liquidity: A Long-Run Empirical Analysis

Ruslan Y. Goyenko and Andrey D. Ukhov

Is the Value Premium a Proxy for Time-Varying Investment Opportunities: Some Time-Series

Evidence

Hui Guo, Robert Savickas, Zijun Wang, and Jian Yang

Managerial Traits and Capital Structure Decisions

Dirk Hackbarth

A Joint Framework for Consistently Pricing Interest Rates and Interest Rate Derivatives Massoud Heidari and Liuren Wu

Insiders' Tax Preferences and Firm's Choice between Dividends and Share Repurchases

Jim Hsieh and Qinghai Wang

Testing Theories of Capital Structure and Estimating the Speed of Adjustment

Rongbing Huang and Jay R. Ritter

Portfolio Concentration and the Performance of Individual Investors

Zoran Ivkovich, Clemens Sialm, and Scott Weisbenner

Testing for the Elasticity of Corporate Yield Spreads

Gady Jacoby, Rose C. Liao, and Jonathan A. Batten

The Information Content of Idiosyncratic Volatility

George J. Jiang, Danielle Xu, and Tong Yao

Managers' and Investors' Responses to Media Exposure of Board Ineffectiveness

Jennifer R. Joe, Henock Louis, and Dahlia Robinson

Irreversible Investment, Financing, and Bankruptcy Decisions in an Oligopoly

Jyh-bang Jou and Tan Lee

Understanding the Penalties Associated with Corporate Detecting Liquidity Traders

Avner Kalay and Avi Wohl

The Cost to Firms of Cooking the Books

Jonathan M. Karpoff, D. Scott Lee, and Gerald S. Martin

The Impact of Commercial Banks on Underwriting Spreads: Evidence From Three Decades Dongcheol Kim, Darius Palia, and Anthony Saunders

Investment Banking and Analyst Objectivity: Evidence from Analysts Affiliated with M\&A Advisors Adam C. Kolasinski and S. P. Kothari

Dynamic Style Preferences of Individual Investors and Stock Returns

Alok Kumar 


\section{Forthcoming Articles (continued)}

Home Biased Analysts in Emerging Markets

Sandy Lai and Melvyn Teo

Testing International Asset Pricing Models Using Implied Costs of Capital

Charles Lee, David Ng, and Bhaskaran Swaminathan

The Costs of Owning Employer Stocks: Lessons from Taiwan

Yi-Tsung Lee, Yu-Jane Liu, and Ning Zhu

Macroeconomic News, Order Flows, and Exchange Rates

Ryan Love and Richard Payne

Misconduct: An Empirical Examination of Earnings and Risk

Deborah L. Murphy, Ronald E. Shrieves, and Samuel L. Tibbs

The Adaptive Markets Hypothesis: Evidence from the Foreign Exchange Market

Christopher J. Neely, Paul A. Weller, and Joshua M. Ulrich

Firm Characteristics, Relative Efficiency, and Equity Returns

Giao X. Nguyen and Peggy E. Swanson

Institutional Investors, Past Performance, and Dynamic Loss Aversion

Paul G. J. O'Connell and Melvyn Teo

New Evidence of Asymmetric Dependence Structures in International Equity Markets Tatsuyoshi Okimoto

Capital Market Imperfections and the Sensitivity of Investment to Stock Prices

Alexei V. Ovtchinnikov and John J. McConnell

The Genesis of Home Bias? The Location and Portfolio Choices of Investment Company

Start-Ups

Jerry T. Parwada

Are Household Portfolios Efficient? An Analysis Conditional on Housing

Loriana Pelizzon and Guglielmo Weber

Recovering Risk-Neutral Densities from Option Prices: A New Approach

Leonidas S. Rompolis and Elias Tzavalis

The (Poor) Predictive Performance of Asset Pricing Models

Timothy Simin

Liquidity, Investment Style, and the Relation between Fund Size and Fund Performance Xuemin (Sterling) Yan

Debt Capacity, Cost of Debt, and Corporate Insurance

Hong Zou and Mike B. Adams 


\section{IFA Journal of Financial and Quantitative Analysis 2008 Subscription Information}

The Journal of Financial and Quantitative Analysis (JFQA) is published quarterly in March, June, September, and December by the School of Business Administration at the University of Washington in Seattle, Washington, U.S.A. Topics include corporate finance, investments, capital and security markets, and quantitative methods of particular relevance to financial researchers. With a circulation of 3000 libraries, firms, and individuals in 70 nations, the JFQA serves an international community of sophisticated finance scholars-academics and practitioners alike. The JFQA prints $8 \%$ of the more than 600 unsolicited manuscripts submitted annually. An intensive blind review process and exacting editorial standards contribute to the JFQA's reputation as a top finance journal.

Payment in advance is required. Checks or money orders must be payable to the JFQA in U.S. dollars for deposit in a U.S. bank. Subscriptions start with the next available issue unless otherwise requested. Online access is available to current individual subscribers of paid print subscriptions. Claims for missing issues must be made within six months of the publication date.

To inquire about permission to reprint or the availability of specific back issues (at a cost of $\$ 30$ per copy), contact the JFQA office.

Library or Firm
Individual
Student (with current verification)
U.S.

$\$ 160$

$\$ 80$

$\$ 25$

International
$\$ 180$
$\$ 100$
$\$ 30$

Total Amount Paid

City State

ZIP addresses)

Country E-mail

Phone Fax

Payment made by: $\quad$ aCheck $\quad$ पVISA $\quad \square$ MasterCard $\quad \square$ American Express

Account No.

Cardholder's Name

Mail or fax directly to:

Journal of Financial and Quantitative Analysis

University of Washington

School of Business Administration

115Lewis

Box 353200

Seattle, WA $98195-3200$ U.S.A.

Phone: (206) 543-4598

Fax: (206) 616-1894

Federal Identification No.: 91-6001537
Exp. Date (mm/yyyy) Today's Date

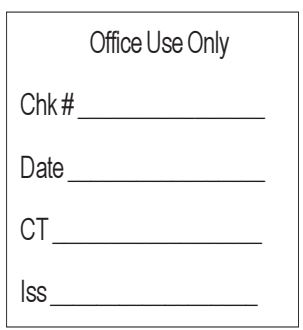

E-mail: jfqa@u.washington.edu ISSN: 0022-1090

URL: http://www.jfqa.org 